\title{
Little pigeons can carry great messages: potential distribution and ecology of Uranotaenia (Pseudoficalbia) unguiculata Edwards, 1913 (Diptera: Culicidae), a lesser- known mosquito species from the Western Palaearctic
}

Serhii Filatov

\begin{abstract}
Background: Uranotaenia unguiculata is a Palaearctic mosquito species with poorly known distribution and ecology. This study is aimed at filling the gap in our understanding of the species potential distribution and its environmental requirements through a species distribution modelling (SDM) exercise. Furthermore, aspects of the mosquito ecology that may be relevant to the epidemiology of certain zoonotic vector-borne diseases in Europe are discussed.

Results: A maximum entropy (Maxent) modelling approach has been applied to predict the potential distribution of Ur. unguiculata in the Western Palaearctic. Along with the high accuracy and predictive power, the model reflects well the known species distribution and predicts as highly suitable some areas where the occurrence of the species is hitherto unknown.

Conclusions: To our knowledge, the potential distribution of a mosquito species from the genus Uranotaenia is modelled for the first time. Provided that Ur. unguiculata is a widely-distributed species, and some pathogens of zoonotic concern have been detected in this mosquito on several occasions, the question regarding its host associations and possible epidemiological role warrants further investigation.
\end{abstract}

Keywords: Culicidae, Uranotaenia unguiculata, Modelling, Potential distribution, Ecology, Vector-borne diseases

\section{Background}

Uranotaenia unguiculata is the only species of the tribe Uranotaeniini Lahille, 1904 presently known to occur in Europe. Originally described from the Lake Kinneret area in Israel [1], the species for a long time was considered as a single representative of the genus in the entire Palaearctic region. More recently, Harbach \& Schnur [2] reported the presence of another species, Ur. (Pseudoficalbia) mashonaensis Theobald, 1901, in the same area in Israel. Interestingly, this finding highlights that this group of mosquitoes is grossly understudied in the region.

Correspondence: filatovmidge@gmail.com

National Scientific Center Institute of Experimental and Clinical Veterinary

Medicine, Kharkiv, Ukraine
Compared with the other, better-studied species of the Culicidae, very little is known about bionomics of Ur. unguiculata throughout its range. Immature stages of the species can be found from May to October across a variety of habitats, both in natural and urbanized areas [3-5]. Thus, larvae occur mostly in stagnant permanent, fresh or slightly brackish (up to 1000$1100 \mathrm{mg} / \mathrm{l}$ ) water bodies, often overgrown with higher aquatic vegetation [5-8]; occasionally, they have also been found in more ephemeral environments such as rice paddies, puddles, hoof prints, and artificial containers $[3,9,10]$. Associations with instars of the following mosquito species have been recorded in the literature: Anopheles algeriensis, An. hyrcanus, An. 
maculipennis (s.l.), An. sacharovi, An. sergentii, An. superpictus, Culex antennatus, $C x$. judaicus, Cx. laticinctus, Cx. mimeticus, Cx. modestus, Cx. pipiens pipiens, $C x$. perexiguus, Cx. theileri, Cx. univittatus, Culiseta alaskaensis, Cs. longiareolata, Cs. subochrea, and Ochlerotatus caspius [3, 5-8, 11-16], which evidently suggest a broad ecological plasticity of Ur. unguiculata.

Even less is known regarding the ecology of adult stages, including the preferred host range, seasonal and daily activity patterns, and dispersal capabilities. Thus, Ur. unguiculata has repeatedly been referred to as an ornithophilic mosquito $[17,18]$ or feeding on amphibian and reptilian hosts has been suggested for the species, largely by the analogy with its congeners [5]. From this point of view, it is interesting to note that the females are attracted to light traps, which are routinely supplemented with carbon dioxide as a bait under the current mosquito surveillance schemes in Europe (e.g. [19, 20]). Although these data are rather inconclusive, with regard to the nature of this attraction, as for example, both sexes can be attracted to black light alone (SF, unpublished observations), at least in two instances female specimens of Ur. unguiculata were collected in traps using $\mathrm{CO}_{2}$ only $[20,21]$. Independently from the used methods, the species is rarely collected in sufficient quantities, which usually leads authors to exclude it from any further ecological analysis (e.g. [22]). According to limited field observations, Ur. unguiculata presumably is a multivoltine mosquito [23], overwintering as unfed, inseminated, nulliparous females, usually in human-made shelters such as cellars, or in reed (Phragmites spp.) piles and under dense marsh vegetation in natural conditions [24-26]. Autogenous egg production has also been observed in some populations of this species [27, 28].

Although it has been widely recognized that Uranotaenia spp. are challenging to sample, especially in the adult stage [29-32], the lack of knowledge regarding ecology and distribution of these mosquitoes might have its consequences for our understanding of some vector-borne diseases that pose a threat to animal and human health. Namely, several strains of West Nile virus (WNV) (Flaviviridae: Flavivirus) have been repeatedly isolated from Ur. unguiculata in different parts of Europe [33-36] and a hypothesis regarding the possible role of the species in the virus overwintering has been suggested [26].

Modelling suitable habitats for arthropod vectors of human and animal diseases is a growing application of species distribution modelling (SDM) which helps in elucidating species-environment relationships and therefore can be used to support epidemiological studies or target disease surveillance [37-40]. A variety of methods such as Maximum Entropy (Maxent), Boosted Regression Trees (BRT), and Genetic Algorithm for Rule-set Production (GARP) have been widely explored and implemented to construct SDMs for mosquito vectors over the last decade [41-48]. Given the scarcity of information regarding the distribution and ecology of Ur. unguiculata across its range, it has been decided to model a potential distribution of the species with the aid of Maxent, which is a popular, userfriendly tool for predicting species distributions. Moreover, other aspects of the species fundamental niche such as trophic interactions and their potential consequences for the epidemiology of vector-borne diseases are being discussed in the present communication.

\section{Methods}

\section{Study area and distributional data}

Contrary to the geographical extent accepted by some of the recent works on the zoogeography of the Western Palaearctic Culicidae (e.g. Porretta et al. [49]), in the scope of this study borders of the region are defined as reported by De Lattin [50]. This area encompasses Europe, North Africa and the Eastern Mediterranean, and a vast area of South-Central Asia that lies west of China and is relatively well delimited by high Central Asian mountain ranges such as the Tien Shan and Karakoram mountains from the south. Moreover, as the exact borders between the Palaearctic and neighbouring biogeographical realms are often considered arbitrary, and for the sake of utility, the broad rectangular area lying between latitude $20-60^{\circ} \mathrm{N}$ and longitude $20^{\circ} \mathrm{W}$ to $80^{\circ} \mathrm{E}$ has been chosen for the modelling exercise. Hence the study area encompasses the entire species range reported in the literature $[5,7,51]$.

Presence records for Ur. unguiculata unguiculata were compiled from a variety of sources, including review of the major literature on ecology and faunistics of Palaearctic Culicidae (see Additional file 1 for the literature search protocol); records held in Zoological Institute of the Russian Academy of Sciences, Saint Petersburg (A.V. Khalin, pers. comm.), Walter Reed Biosystematics Unit, Smithsonian Institution, Washington DC (accessed through the VectorMap data portal: http://www.vectormap.org, on 27 October 2015); through personal communications from a number of mosquito experts (see the Acknowledgements); as well as from the author's own findings of the species in eastern and southern regions of Ukraine. For a substantial proportion of the data (mostly literature records) the exact presence points were unavailable and geographical coordinates were assigned using GeoLocate Web Application (http://www.museum.tulane.edu/geolocate/web/WebGeoref.aspx). Only localities that could be determined unambiguously were used for the georeferencing and included in the dataset, which consists of 308 spatially unique occurrence points (Fig. 1), spanning the period between 1913 and 2015. To augment availability of the distributional information, the data are provided as Additional file 2: Table S1. 


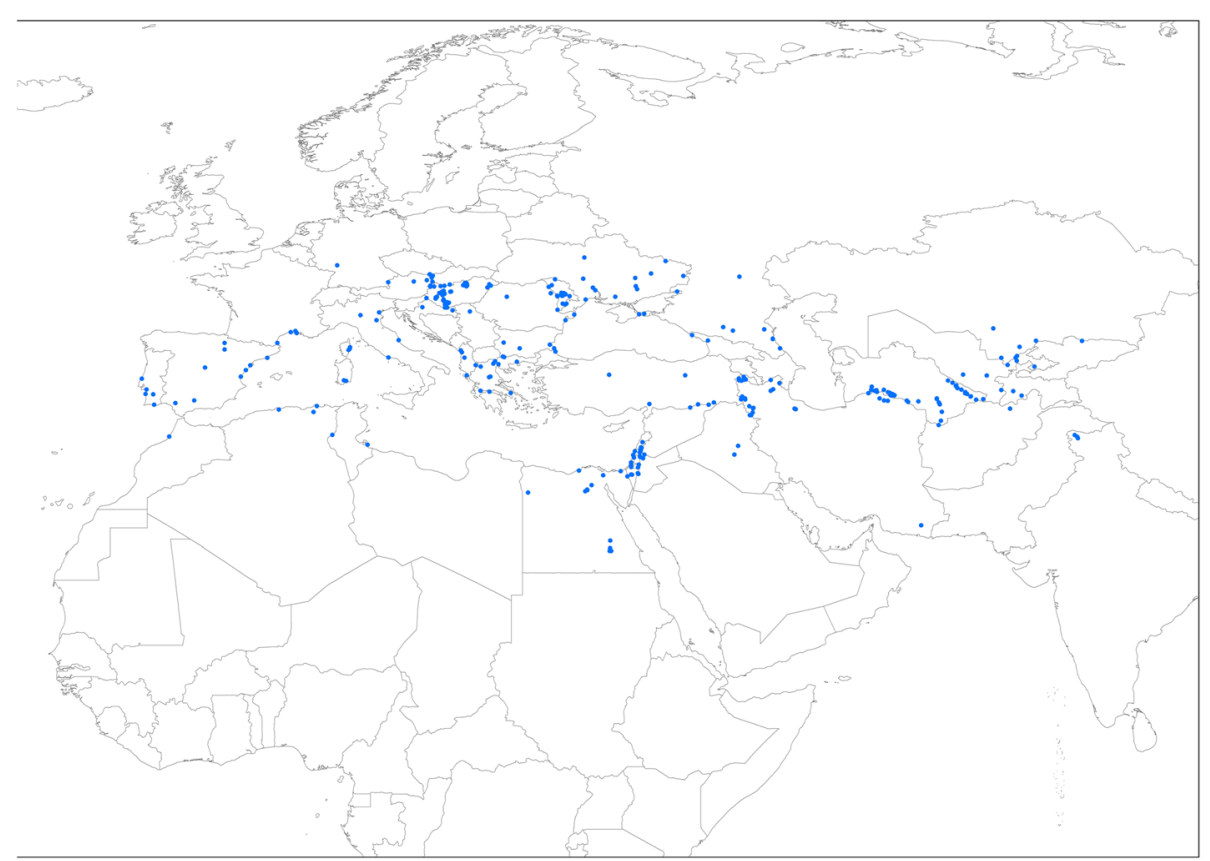

Fig. 1 Distributional records of Uranotaenia unguiculata in the Western Palaearctic

\section{SDM development procedure}

Maxent is a dedicated software based on the maximumentropy approach for modelling species niches and distributions using their occurrence records together with a set of user-defined environmental predictor variables (i.e. temperature, precipitation) for a surrounding study area $[52,53]$. This method was chosen because of its high performance, robustness, and, importantly, because of its ability to accurately predict species distributions from small numbers of occurrences [37, 54-56]. Briefly, Maxent predicts habitat suitability for a given species by comparing environmental predictors at sites where it has been recorded with background sites across the study area. The resulting (default) logistic output is visualized and interpreted as a habitat suitability index ranging from 0 (unsuitable) to 1 (highly suitable habitat) per grid cell [56-58].

Predictor variables used in the process of the model building must be ecologically relevant and ideally, as proximal as possible to the factors limiting the modelled species' distribution [59]. A multitude of different environmental predictors has been used in SDM development for mosquitoes with temperature and precipitation variables (Bioclim) being the most widespread [41-47, 60-63]. Along with the climatic predictors, other types of variables such as elevation, land-cover, land use, and host population density have been complementary explored in some of these studies and found to be important contributors to the models [41, 45, 62]. However, as some of these variables (e.g. elevation) are distal to the true limiting factors [64] or largely are not available at broad spatial and temporal scales, it has been decided to use only Bioclim data as predictor variables in the present study. This dataset generated through interpolation of average monthly data from numerous meteorological stations over a 50-year period (1950-2000) [65] is available on a worldwide scale and broadly matches the temporal extent of the occurrence dataset for Ur. unguiculata.

Nineteen bioclimatic variables at a spatial resolution of 30 arc-seconds $\left(\sim 1 \times 1 \mathrm{~km}^{2}\right.$ grid cells) were downloaded from the WorldClim database (http://www.worldclim.org/ bioclim), clipped to the study area extent and prepared for use in Maxent with the aid of the ArcMap 10.3.1 free extension toolkit SDM toolbox v.1.1c [66]. Subsequently, to be able to make inferences on the predictor variable importance, the environmental layers were checked for collinearity using the "Explore Climate: Correlations and Summary Stats tool" within the same toolkit and highly correlated (Pearson's correlation coefficient $>0.80$, see Additional file 3: Table S2) were removed from the list. A decision on whether to remove or retrieve a variable was also made on the basis of their percent contribution to the model obtained during a preliminary run in Maxent 3.3.k with the full set of environmental layers and presence records. The resulted list of predictors used for the final model development consisted of 11 variables (Table 1).

Spatial clustering of occurrence points in some areas was evident in our dataset; and therefore, in order to avoid problems related to uneven sampling efforts and spatially autocorrelated records, which pertain to most if 
Table 1 Nineteen environmental variables obtained from the WorldClim dataset (http://worldclim.org)

\begin{tabular}{ll}
\hline Variable & Description \\
\hline bio1 & Annual mean temperature \\
bio2 & Mean diurnal range \\
bio3 & Isothermality \\
bio4 & Temperature seasonality \\
bio5 & Maximum temperature of warmest month \\
bio6 & Minimum temperature of coldest month \\
bio7 & Temperature annual range \\
bio8 & Mean temperature of wettest quarter \\
bio9 & Mean temperature of driest quarter \\
bio10 & Mean temperature of warmest quarter \\
bio11 & Mean temperature of coldest quarter \\
bio12 & Annual precipitation \\
bio13 & Precipitation of wettest month \\
bio14 & Precipitation of driest month \\
bio15 & Precipitation seasonality \\
bio16 & Precipitation of wettest quarter \\
bio17 & Precipitation of driest quarter \\
bio18 & Precipitation of warmest quarter \\
bio19 & Precipitation of coldest quarter \\
\hline
\end{tabular}

${ }^{a}$ Variables used in the analysis

not all presence-only data gathered from museum records, online databases, etc. $[67,68]$, the original occurrence dataset was reduced within a specified Euclidean distance of $50 \mathrm{~km}$ (a distance exceeding the average maximum flight distance reported for the Culicidae [69]) using the "Spatially Rarefy Occurrence Data for SDMs" tool in the SDM toolbox. This resulted in a spatially rarefied dataset consisting of 151 occurrences, which was subsequently used for the modelling exercise.

For the final model run Maxent was set-up with the default settings except for the following: the regularization multiplier of 2 , as the higher regularization parameter limits model complexity and reduce overfitting [70], and the random test percentage of 25 has been chosen as a simple test of model fit previously used by number of SDM studies for hematophagous vectors in the absence of independent data for model validation [40]. The resulted SDM was processed and visualized in the ArcMap 10.3.1.

As a measure of a model's discriminative power Maxent calculates the area under the curve (AUC) for the receiver operation characteristic (ROC) score, which typically ranges between 0.5 (indicates no better than random prediction) and 1.0 (i.e. a perfect fit) [52, 71]. Additionally, to allow users to explore the importance of predictors, Maxent performs variable jackknifing, a procedure which builds multiple models excluding different variables and compares the models' performance with and without each variable [72].

\section{Results}

Figure 2 shows model predictions for the potential distribution of Ur. unguiculata in the Western Palaearctic with the resulting area under the receiver operating characteristic (AUC) values of 0.913 and $0.882 \pm 0.026$ SD for the training and test data, respectively, which indicate high accuracy and predictive power of the model. Furthermore, the minimum training presence binomial probability of $P<0.001$ shows that the model performance was better than random [73].

Summary data on the percent contribution and permutation importance for each environmental variable used in the analysis are presented in Table 2. Mean temperature of the warmest quarter (bio10) was a variable with highest percent contribution, followed by precipitation of the coldest quarter (bio19), and min temperature of the coldest month (bio6).

According to the jackknife test (Fig. 3), mean temperature of the coldest quarter (bio11) was the variable having the highest training gain when used alone, which indicates that it has the most useful information by itself; whereas mean temperature of warmest quarter (bio 10) decreased training gain the most when was excluded from the analysis and therefore has the most information that is not present in other variables.

\section{Discussion}

Although this study has several limitations resulting from the spatial and temporal biases and inaccuracies inherent in the types of data used in the analysis [74-76], the model is an appropriate first step to increase our understanding of the distribution of Ur. unguiculata $[77,78]$. The known distribution of the species is well reflected by the model with only a few occurrence points falling outside the predicted range (Fig. 2). Moreover, most of the observed mismatches fall within the Saharo-Arabian subregion, a wellrecognized biogeographical transition zone $[79,80]$ where at least two other Uranotaenia species have been reported to occur sympatrically with Ur. unguiculata $[2,81]$. From this perspective, it is important to note that although the species is usually considered as immediately recognizable and easily identifiable throughout its range, it took some additional effort to realize that, for example, the specimens of Uranotaenia collected in Morocco belonged in the two separate taxa, a common Palaearctic Ur. unguiculata and an Afrotropical Ur. balfouri [81]. Hence, care should be taken when considering the records from areas with a strong influence of neighbouring biogeographical realms, which might represent misidentifications. The situation is further complicated by the fact that the subspecies Ur. unguiculata pefflyi has been described from the Arabian Peninsula [82], which renders the species polytypic. Given that the actual nature of this variability is essentially unknown, distributional data for Ur. unguiculata pefflyi were not included in 


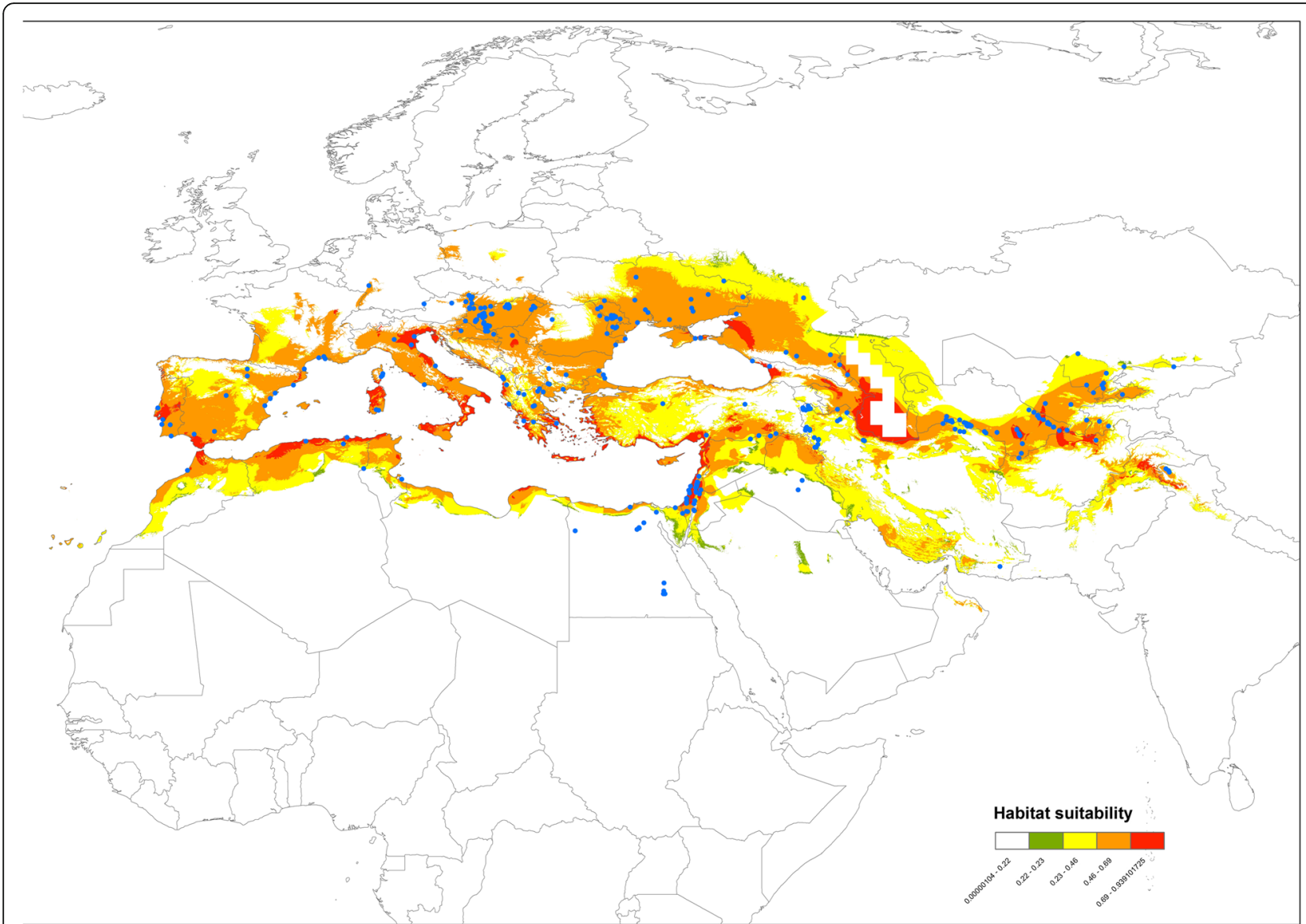

Fig. 2 Model predictions for the potential distribution of Uranotaenia unguiculata in the Western Palaearctic together with the species occurrence records. The value of predicted environmental suitability was classified into five categories including very high suitability (red), high suitability (orange), moderate suitability (yellow), low suitability (green), and unsuitable (white)

Table 2 Summary of the average percent contribution and permutation importance for each of the environmental variables

\begin{tabular}{lll}
\hline Variable & Percent contribution & Permutation importance \\
\hline bio10 & 35.4 & 28.0 \\
bio19 & 34.7 & 18.8 \\
bio6 & 12.8 & 8.1 \\
bio2 & 8.0 & 7.2 \\
bio8 & 2.9 & 3.6 \\
bio11 & 2.2 & 29.1 \\
bio7 & 2.2 & 1.8 \\
bio18 & 1.0 & 2.5 \\
bio13 & 0.5 & 0.6 \\
bio12 & 0.2 & 0.3 \\
bio17 & 0.1 & 0 \\
\hline
\end{tabular}

the present analysis. The subspecific status of the Arabian populations could imply either classic allopatric speciation with niche conservatism, which would result in predicting these localities as suitable in the present model or intraspecific niche differentiation with poor habitat suitability predicted for the area [83, 84]. Albeit the data scarcity did not allow to model the distribution of this subspecies directly, the potential distribution of the nominal subspecies observed in the present study suggests the latter scenario. More information on the occurrence and preferably molecular data on the genetic variability of both subspecies in the region are needed to solve this problem.

The predicted areas of high habitat suitability within the European part of the range are in good agreement with known species records. At the same time, some areas in central and western Europe where occurrences for Ur. unguiculata are hitherto unknown surprisingly received a relatively high suitability index in the model. Thus, some areas in Poland (e.g. lower part of the River Oder basin in the Lubusz and Lower Silesian voivodeships, or even small coastal stretches on the Baltic 


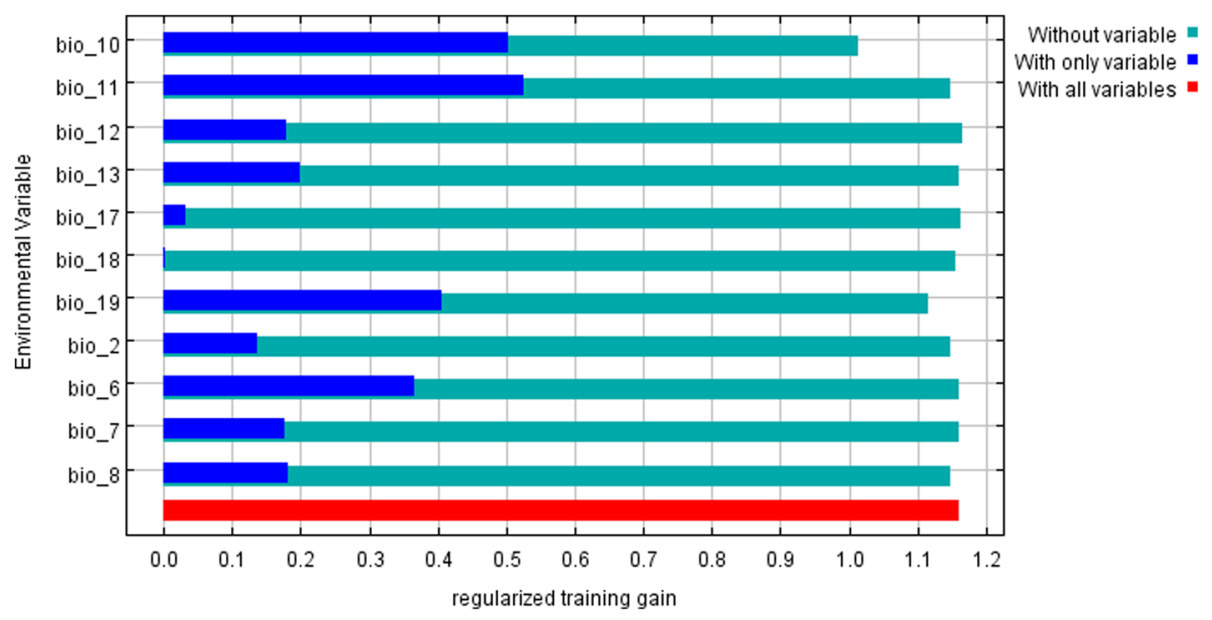

Fig. 3 Jackknife of regularized training gain

shores near Kołobrzeg and Ustka located at some $54^{\circ} \mathrm{N}$ latitude!) represent suitable habitats according to the model results. Although it is unlikely that the species occurs so far north as the $54^{\circ}$ latitude, it is reasonable to assume that the observed prediction reflects species' true environmental requirements as inferred from the climatic variables, while it does not account for the array of other factors such as biotic interactions, climate equilibrium, and historical dispersal constraints [78, 85]. Similarly, the Canary Islands that have relatively poor mosquito fauna with only 11 species recorded so far [86] have been predicted by the model as largely suitable for Ur. unguiculata, although the archipelago is apparently unoccupied by the species, possibly as the result of its remoteness and recent volcanic origin.

Conversely, it has been conjectured that records of Ur. unguiculata from the Upper Rhine Valley in Germany [87] and the South Moravian Region of the Czech Republic [19] might represent a recent range expansion due to the global warming. However, as predicted by the model, these regions represent highly suitable areas and more likely serve as thermophilic refugia persisting at least since the Holocene climatic optimum [88], or even represent much older Pleistocenic extra-Mediterranean refugia, which have been increasingly recognized for various plant and animal taxa in Europe [89]. This should be unveiled with the new methods such as phylogenetic analysis of mtDNA sequencing data coupled with the species distribution models, which show great promise for understanding the patterns of biodiversity.

Although a full assessment of the species environmental requirements was behind the scope of the present study, the results of the jackknife test reveal interesting relationships between the mean temperatures of coldest (bio11) and warmest (bio10) quarters. The importance of winter temperatures as a factor limiting northerly distribution of temperate mosquitoes and expressed as a mean January isotherm has been elucidated for Aedes albopictus (reviewed in [90]), whereas sufficient summer temperatures are thought to be critical for immature development and the growth rates of mosquito populations [91]. It is possible that an interplay between the two variables is a factor that partially determines the presence of many thermophilic species in temperate latitudes, which is further supported by the notion that in areas "where 'summer' temperatures are high the effect of harsh 'winter' temperatures is less damaging" [92].

Interestingly, many of the species records utilized in the present analysis came from extensive wetland areas suggesting that the mosquito's ecological niche might be overlapping with that of WNV in Europe [93]. Thus, the lineage $4 \mathrm{WNV}$ has been detected in Ur. unguiculata pools from the Lower Volga region in Russia [33] and from mosquitoes collected in the Danube Delta, Romania [36]. Although the pathogenicity of the WNV strains isolated from Ur. unguiculata remains to be fully characterized and the species does not meet the classical criteria used to define a competent disease vector [94], further inquiries into the vector-pathogen-host interactions might prove useful for a better understanding of WNV evolution, routes of emergence and circulation in Europe. It is worth mentioning that currently Ur. unguiculata is rather perceived as an entomological curiosity among most European vector-borne disease specialists. However, this point of view is based on the species obscurity and a poor empirical knowledge of its ecology. One of the critical gaps is the lack of information regarding host preference and feeding behavior of the species. Indeed, although there is limited evidence in the literature that supports the notion that Ur. unguiculata feeds on the blood of poikilothermic animals [95-97], several field observations point out that the species do occasionally feed on mammalian hosts, including humans [98-100]. Together with the recent detection of canine 
parasitic nematodes Dirofilaria repens in pools of Ur. unguiculata from Moldova [101], this strongly suggests much broader host range for this mosquito species and its possible relevance to the circulation of zoonotic pathogens in Europe.

\section{Conclusions}

To the best of the author's knowledge, this study reports the first species distribution model for any of the representatives of the genus Uranotaenia. The results of the species distribution modelling exercise provide first insights into potential distribution and ecological requirements of Ur. unguiculata across the Western Palaearctic region. Provided that the species has a wide distribution and some pathogens of zoonotic concern have been detected in this mosquito on several occasions, the question regarding its host associations and possible epidemiological role warrants further investigation.

\section{Additional files}

Additional file 1: Literature searches strategy and bibliography used to compile the occurrence dataset for Uranotaenia unguiculata. (PDF $666 \mathrm{~kb}$ )

Additional file 2: Table S1. Occurrence dataset for Uranotaenia unguiculata. (XLSX $29 \mathrm{~kb}$ )

Additional file 3: Table S2. Correlation matrix of the Bioclim environmental layers. Positive and negative correlations $(\geq 0.80$ or $\leq-0.80)$ are shown in red. For variable names refer to the Table 1. (XLSX $12 \mathrm{~kb})$

\section{Abbreviations}

BRT: Boosted Regression Trees; GARP: Genetic Algorithm for Rule-set Production; Maxent: Maximum Entropy; SDM: Species distribution modelling; WNV: West Nile virus

\section{Acknowledgments}

The author is greatly indebted to the following researchers, who contributed their field data and thus made the study possible: Tatiana Suleșco (Institute of Zoology, Academy of Sciences of Moldova), Alexei Vladimirovich Khalin (Zoological Institute, Russian Academy of Sciences), Horst Aspöck (Medical University of Vienna), Carina Zittra \& Karin Lebl (University of Veterinary Medicine, Vienna), Peter Hufnagl (Austrian Agency for Health and Food Safety), Zoltán Kenyeres (Acrida Conservational Research L.P.), Sándor Tóth (Budapest University of Technology and Economics), Filiz Gunay (Hacettepe University), Shahyad Azari-Hamidian (School of Health, Guilan University of Medical Sciences), Peter Bitušík (Faculty of Natural Sciences, Matej Bel University). Many thanks are due to Ognyan Mikov (National Centre of Infectious and Parasitic Disease, Bulgaria) for his help with the literature on the species distribution in Bulgaria.

\section{Funding}

Not applicable.

\section{Availability of data and materials}

All data analyzed during this study are included within the article and its additional files or available from the author on reasonable request.

\section{Authors' contributions}

Not applicable.

Ethics approval and consent to participate

Not applicable.

\section{Consent for publication}

Not applicable.

\section{Competing interests}

The author declares that he has no competing interests.

\section{Publisher's Note}

Springer Nature remains neutral with regard to jurisdictional claims in published maps and institutional affiliations.

Received: 23 May 2017 Accepted: 27 September 2017

Published online: 10 October 2017

\section{References}

1. Edwards FW. Tipulidae and Culicidae from the Lake of Tiberias and Damascus. J Proc Asiatic Soc Bengal. 1913;9(1):47-51.

2. Harbach RE, Schnur HJ. Uranotaenia (Pseudoficalbia) mashonaensis, an afrotropical species found in Northern Israel. J Am Mosq Control Assoc. 2007;23(2):224-5.

3. Sulesco TM, Toderas LG, Uspenskaia IG, Toderas I. Larval habitats diversity and distribution of the mosquito (Diptera: Culicidae) species in the Republic of Moldova. J Med Entomol. 2015;52(6):1299-308.

4. Zittra C, Vitecek S, Obwaller AG, Rossiter H, Eigner B, Zechmeister T, et al. Landscape structure affects distribution of potential disease vectors (Diptera: Culicidae). Parasit Vectors. 2017;10(1):205.

5. Becker N, Petric D, Zgomba M, Boase C, Minoo M, Dahl C, Kaiser A. Mosquitoes and their control. Berlin Heidelberg: Springer; 2010.

6. Dubitsky AM. [The blood-sucking mosquitoes of Kazakhstan.] Alma-Ata: Nauka; 1970. (In Russian)

7. Gutsevich AV, Monchadskii AS, Stackelberg AA. [Fauna USSR. Diptera. III. 4. Mosquitoes. Family Culicidae.] Leningrad: Nauka; 1970. (In Russian).

8. Melero-Alcíbar R, Aranda C, Molina R. Re-description of the pupa of Uranotaenia unguiculata (Diptera: Culicidae) and a morphological key for identification of pupae of mosquito genera in the Palaearctic Region. Eur Mosq Bull. 2010;28:45-50.

9. Liberato CD, Magliano A, Farina F, Toma L. Recent entomological enquiry on mosquito fauna in Circeo National Park. Ann Ist Super Sanita. 2015;51(3):224-8.

10. Lytra I, Emmanouel N. Study of Culex tritaeniorhynchus and species composition of mosquitoes in a rice field in Greece. Acta Trop. 2014;134:66-71.

11. Moussiegt O. Aedes ochlerotatus caspius Pallas, 1771, Bibliographie - supplément., vol. 15. Montpellier: E.I.D; 1988.

12. Azari-Hamidian S. Larval habitat characteristics of mosquitoes of the genus Culex (Diptera: Culicidae) in Guilan Province, Iran. J Arthropod Borne Dis. 2007;1(1):9-20.

13. Amr ZS, Al-Khalili Y, Arbaji A. Larval mosquitoes collected from northern Jordan and the Jordan Valley. J Am Mosq Control Assoc. 1997;13(4):375-8.

14. Beier J, Kenawy M, el Said S, Merdan A. Vector potential of culicine mosquitoes in Faiyum Governorate, Egypt. J Am Mosq Control Assoc. 1986; 2(2):164-7.

15. Şimşek FM. Seasonal larval and adult population dynamics and breeding habitat diversity of Culex theileri Theobald, 1903 (Diptera: Culicidae) in the Gölbaşı district, Ankara, Turkey. Turk J Zool. 2004;28(4):337-44.

16. Al-Khalili YH, Katbeh-Bader A, Amr Z. Distribution and ecology of mosquito larvae in Jordan (Diptera: Culicidae). Stud Dipterol. 2000;7(1):179-88.

17. Petrischeva PA. [Fauna, ecology and biology of Turkmenian Culicidae.] Parazitol Sbornik. 1936;6:49-115. (In Russian).

18. Becker N, Hoffmann D. First record of Culiseta longiareolata (Macquart) for Germany. Eur Mosq Bull. 2011;29:143-50.

19. Šebesta O, Gelbič I, Minář J. Mosquitoes (Diptera: Culicidae) of the Lower Dyje River Basin (Podyjí) at the Czech-Austrian border. Cent Eur J Biol. 2012; 7(2):288-98

20. Calzolari M, Zé-Zé L, Růžek D, Vazquez A, Jeffries C, Defilippo F, et al. Detection of mosquito-only flaviviruses in Europe. J Gen Virol. 2012;93(6): 1215-25.

21. Roiz D, Roussel M, Muñoz J, Ruiz S, Soriguer R, Figuerola J. Efficacy of mosquito traps for collecting potential West Nile mosquito vectors in a natural Mediterranean wetland. Am J Trop Med Hyg. 2012;86(4):642-8.

22. Roiz D, Ruiz S, Soriguer R, Figuerola J. Landscape Effects on the Presence, Abundance and diversity of mosquitoes in Mediterranean wetlands. PLoS One. 2015;10(6):e0128112.

23. Török E, Tomazatos A, Cadar D, Horváth C, Keresztes L, Jansen S, et al. Pilot longitudinal mosquito surveillance study in the Danube Delta Biosphere Reserve and the first reports of Anopheles algeriensis Theobald, 1903 and Aedes hungaricus Mihályi, 1955 for Romania. Parasit Vectors. 2016;9(1):196. 
24. Mouchet J, Rageau J. Observations sur les moustiques I. L'hibernation d' Uranotaenia unguiculata Edwards, 1913 (Diptère Culicidae) de la Camargue et du Bas-Rhone. Bull Soc Pathol Exot. 1965;58:246-50.

25. Mouchet J, Rageau J, Chippaux A. Hibernation de Culex molestus (Ficalbi) (Diptera: Culicidae) en Camargue. Cah ORSTOM Ser Entomol Med Parasitol. 1969;7:35-7.

26. Rudolf I, Šebesta O, Straková P, Betášová L, Blažejová H, Venclíková K, et al. Overwintering of Uranotaenia unguiculata adult females in central Europe: A possible way of persistence of the putative new lineage of West Nile Virus? J Am Mosq Control Assoc. 2015;31(4):364-5.

27. Babayants GA, Karapet'yan AB. [On the autogenous development of the ovaries in some species of mosquitos of Turkmenia.] Med Parazitol i Parazit Bol. 1970;39(1):24-9. (In Russian).

28. Mattingly PF, Rozeboom LE, Knight $\mathrm{KL}$, Laven $\mathrm{H}$, Drummond FH, Christophers SR, Shute PG. The Culex pipiens complex. Trans R Entomol Soc Lond. 1951;102(7):331-42.

29. Hoshi T, Higa Y, Chaves LF. Uranotaenia novobscura ryukyuana (Diptera: Culicidae) population dynamics are denso-dependent and autonomous from weather fluctuations. Ann Entomol Soc Am. 2014;107(1):136-42.

30. Toma T, Miyagi I. Notes on the mosquitoes collected at forest areas in the northern part of Okinawajima, Ryukyu Islands, Japan. Jpn J Sanit Zool. 1981; 32:271-9.

31. Dampf A. Distribucion y ciclo anual de Uranotaenia syntheta Dyar \& Shannon en Mexico y descripcion del hipopigio masculino (Insecta: Diptera). Rev Soc Mex Hist Nat. 1943;4:147-69.

32. Hinman EH. Biological notes on Uranotaenia spp. in Louisiana (Culicidae, Diptera). Ann Entomol Soc Am. 1935;28(3):404-7.

33. Shopenskaya TA, Fedorova MV, Karan LS, Frolov AY, Malenko GV, Levina LS, et al. [New variant of West Nile virus and its potential epizootic and epidemic importance.] Epid Inf Bol. 2008;5:38-44. (In Russian).

34. Kemenesi $G$, Dallos B, Oldal M, Kutas A, Földes F, Németh $V$, et al. Putative novel lineage of West Nile virus in Uranotaenia unguiculata mosquito, Hungary. Virusdisease. 2014;25(4):500-3.

35. Pachler K, Lebl K, Berer D, Rudolf I, Hubalek Z, Nowotny N. Putative new West Nile virus lineage in Uranotaenia unguiculata mosquitoes, Austria, 2013. Emerg Infect Dis. 2014;20(12):2119.

36. Dinu S, Cotar A, Pănculescu-Gătej I, Fălcuță E, Prioteasa F, Sîrbu A, et al. West Nile virus circulation in south-eastern Romania, 2011 to 2013. Euro Surveill. 2015;20(20):21130.

37. Franklin J. Mapping species distributions: spatial inference and prediction. New York: Cambridge University Press; 2010.

38. Costa J, Peterson AT. Ecological niche modeling as a tool for understanding distributions and interactions of vectors, hosts, and etiologic agents of Chagas disease. In: Mylonakis E, Ausubel F, Gilmore M, Casadevall A, editors. Recent advances on model hosts. Advances in Experimental Medicine and Biology. New York: Springer; 2012. p. 59-70.

39. Thomas SM, Beierkuhnlein C. Predicting ectotherm disease vector spread - benefits from multidisciplinary approaches and directions forward. Naturwissenschaften. 2013:100(5):395-405.

40. Acheson ES, Kerr JT. Looking forward by looking back: Using historical calibration to improve forecasts of human disease vector distributions. Vector Borne Zoonotic Dis. 2015;15(3):173-83.

41. Conley AK, Fuller DO, Haddad N, Hassan AN, Gad AM, Beier JC. Modeling the distribution of the West Nile and Rift Valley fever vector Culex pipiens in arid and semi-arid regions of the Middle East and North Africa. Parasit Vectors. 2014;7(1):289.

42. Sinka ME, Rubio-Palis $Y$, Manguin S, Patil AP, Temperley WH, Gething PW, et al. The dominant Anopheles vectors of human malaria in the Americas: occurrence data, distribution maps and bionomic précis. Parasit Vectors. 2010;3(1):72.

43. Benedict MQ, Levine RS, Hawley WA, Lounibos LP. Spread of the tiger: Global risk of invasion by the mosquito Aedes albopictus. Vector Borne Zoonotic Dis. 2007;7(1):76-85.

44. Fischer D, Thomas SM, Niemitz F, Reineking B, Beierkuhnlein C. Projection of climatic suitability for Aedes albopictus Skuse (Culicidae) in Europe under climate change conditions. Glob Planet Change. 2011;78(1):54-64.

45. Foley DH, Klein TA, Kim HC, Sames WJ, Wilkerson RC, Rueda LM. Geographic distribution and ecology of potential malaria vectors in the Republic of Korea. J Med Entomol. 2009;46(3):680-92.

46. Fuller DO, Ahumada ML, Quiñones ML, Herrera S, Beier JC. Near-present and future distribution of Anopheles albimanus in Mesoamerica and the
Caribbean Basin modeled with climate and topographic data. Int J Health Geogr. 2012;11(1):13.

47. Koch LK, Cunze S, Werblow A, Kochmann J, Dörge DD, Mehlhorn H Klimpel S. Modeling the habitat suitability for the arbovirus vector Aedes albopictus (Diptera: Culicidae) in Germany. Parasitol Res. 2016; 115(3):957-64.

48. Melaun C, Werblow A, Cunze S, Zotzmann S, Koch L, Mehlhorn H, et al. Modeling of the putative distribution of the arbovirus vector Ochlerotatus japonicus japonicus (Diptera: Culicidae) in Germany. Parasitol Res. 2015; 114(3):1051-61.

49. Porretta D, Canestrelli D, Urbanelli S, Bellini R, Schaffner F, Petric D, Nascetti $G$. Southern crossroads of the Western Palaearctic during the Late Pleistocene and their imprints on current patterns of genetic diversity: insights from the mosquito Aedes caspius. J Biogeogr. 2011;38(1):20-30.

50. De Lattin G. Grundriß der Zoogeographie. Jena: Verlag Gustav Fischer; 1967.

51. Ramsdale CD, Snow KR. Distribution of the genera Coquillettidia, Orthopodomyia and Uranotaenia in Europe. Eur Mosq Bull. 2001;10:25-9.

52. Phillips SJ, Anderson RP, Schapire RE. Maximum entropy modeling of species geographic distributions. Ecol Model. 2006;190(3-4):231-59.

53. Phillips SJ, Anderson RP, Dudík M, Schapire RE, Blair ME. Opening the black box: an open-source release of Maxent. Ecography. 2017;40(7):887-93.

54. Pearson RG, Raxworthy CJ, Nakamura M, Townsend Peterson A. Predicting species distributions from small numbers of occurrence records: a test case using cryptic geckos in Madagascar. J Biogeogr. 2007;34(1):102-17.

55. Shcheglovitova M, Anderson RP. Estimating optimal complexity for ecological niche models: A jackknife approach for species with small sample sizes. Ecol Model. 2013;269:9-17.

56. Elith J, Phillips SJ, Hastie T, Dudík M, Chee YE, Yates CJ. A statistical explanation of MaxEnt for ecologists. Divers Distrib. 2011;17(1):43-57.

57. Guillera-Arroita G, Lahoz-Monfort JJ, Elith J, Gordon A, Kujala H, Lentini PE, et al. Is my species distribution model fit for purpose? Matching data and models to applications. Glob Ecol Biogeogr. 2015:24(3):276-92.

58. Fitzpatrick MC, Gotelli NJ, Ellison AM. MaxEnt versus MaxLike: empirical comparisons with ant species distributions. Ecosphere. 2013:4(5):1-15.

59. Merow C, Smith MJ, Edwards TC, Guisan A, McMahon SM, Normand S, et al. What do we gain from simplicity versus complexity in species distribution models? Ecography. 2014;37(12):1267-81.

60. Pakdad K, Hanafi-Bojd AA, Vatandoost H, Sedaghat MM, Raeisi A, Moghaddam AS, Foroushani AR. Predicting the potential distribution of main malaria vectors Anopheles stephensi, An. culicifacies s.l. and An. fluviatilis s.l. in Iran based on maximum entropy model. Acta Trop. 2017;169:93-9.

61. Sallam MF, Al Ahmed AM, Abdel-Dayem MS, Abdullah MAR. Ecological niche modeling and land cover risk areas for Rift Valley fever vector, Culex tritaeniorhynchus Giles in Jazan, Saudi Arabia. PLoS One. 2013;8(6):e65786.

62. Sallam MF, Xue R-D, Pereira RM, Koehler PG. Ecological niche modeling of mosquito vectors of West Nile virus in St. John's County, Florida, USA. Parasit Vectors. 2016;9(1):371

63. Fatima SH, Atif S, Rasheed SB, Zaidi F, Hussain E. Species distribution modelling of Aedes aegypti in two dengue-endemic regions of Pakistan. Tropical Med Int Health. 2016:21(3):427-36.

64. Bradie J, Leung B. A quantitative synthesis of the importance of variables used in MaxEnt species distribution models. J Biogeogr. 2017;44(6):1344-61.

65. Hijmans RJ, Cameron SE, Parra JL, Jones PG, Jarvis A. Very high resolution interpolated climate surfaces for global land areas. Int J Climatol. 2005; 25(15):1965-78.

66. Brown JL. SDMtoolbox: a python-based GIS toolkit for landscape genetic, biogeographic and species distribution model analyses. Methods Ecol Evol. 2014;5(7):694-700

67. Boria RA, Olson LE, Goodman SM, Anderson RP. Spatial filtering to reduce sampling bias can improve the performance of ecological niche models. Ecol Model. 2014:275:73-7.

68. Veloz SD. Spatially autocorrelated sampling falsely inflates measures of accuracy for presence-only niche models. J Biogeogr. 2009;36(12):2290-9.

69. Verdonschot PFM, Besse-Lototskaya AA. Flight distance of mosquitoes (Culicidae): A metadata analysis to support the management of barrier zones around rewetted and newly constructed wetlands. Limnologica. 2014 45:69-79.

70. Radosavljevic A, Anderson RP. Making better Maxent models of species distributions: complexity, overfitting and evaluation. J Biogeogr. 2014; $41(4): 629-43$ 
71. Fielding AH, Bell JF. A review of methods for the assessment of prediction errors in conservation presence/absence models. Environ Conserv. 1997; 24(1):38-49.

72. Peterson AT. Ecological niches and geographic distributions (MPB-49). Princeton \& Oxford: Princeton University Press; 2011.

73. Anderson RP, Gómez-Laverde M, Peterson AT. Geographical distributions of spiny pocket mice in South America: insights from predictive models. Glob Ecol Biogeogr. 2002;11(2):131-41.

74. Reside AE, Watson I, VanDerWal J, Kutt AS. Incorporating low-resolution historic species location data decreases performance of distribution models. Ecol Model. 2011;222(18):3444-8.

75. Peterson AT. Mapping disease transmission risk: enriching models using biogeography and ecology. Baltimore: JHU Press; 2014.

76. Anderson RP, Raza A. The effect of the extent of the study region on GIS models of species geographic distributions and estimates of niche evolution: preliminary tests with montane rodents (genus Nephelomys) in Venezuela. J Biogeogr. 2010;37(7):1378-93.

77. Peterson AT. Uses and requirements of ecological niche models and related distributional models. Biodivers Inform. 2006:3:59-72.

78. Araújo MB, Peterson AT. Uses and misuses of bioclimatic envelope modeling. Ecology. 2012:93(7):1527-39.

79. Vermeij GJ. When biotas meet: Understanding biotic interchange. Science. 1991;253(5024):1099-104

80. Kreft H, Jetz W. Comment on "An Update of Wallace's Zoogeographic Regions of the World". Science. 2013;341(6144):343.

81. Bailly-Choumara H. Contribution à l'étude des moustiques du Maroc (Diptera, Culicidae): six espèces nouvelles pour le pays. Cahiers ORSTOM Série Entomologie Médicale et Parasitologie. 1968;6(2):139-44.

82. Stone A. A new subspecies of Uranotaenia unguiculata Edwards from Arabia (Diptera: Culicidae). Proc Entomol Soc Wash. 1960;62:249.

83. Peterson AT, Soberón J, Sánchez-Cordero V. Conservatism of ecological niches in evolutionary time. Science. 1999;285(5431):1265-7.

84. Peterson AT, Holt RD. Niche differentiation in Mexican birds: using point occurrences to detect ecological innovation. Ecol Lett. 2003;6(8):774-82.

85. Peterson AT, Lieberman BS. Species' geographic distributions through time: playing catch-up with changing climates. Evol Educ Outreach. 2012;5(4):569-81.

86. Baez M, Fernandez J. Notes on the mosquito fauna of the Canary Islands (Diptera: Culicidae). Mosquito Systematics. 1980;12(3):349-55.

87. Becker $N$, Kaiser $\mathrm{A}$. The mosquitoes (Culicidae) of the drainage area of the Upper Rhine Valley with special consideration of Uranotaenia (Culicidae, Diptera) - a new mosquito genus for Germany.] Mitt Dtsch Ges Allg Angew Entomol. 1995;10(1-6):407-13. (In German).

88. Aspöck H. Postglacial formation and fluctuations of the biodiversity of central Europe in the light of climate change. Parasitol Res. 2008;103(1):7-10.

89. Schmitt T, Varga Z. Extra-Mediterranean refugia: The rule and not the exception? Front Zool. 2012;9(1):22.

90. Medlock JM, Avenell D, Barrass I, Leach S. Analysis of the potential for survival and seasonal activity of Aedes albopictus (Diptera: Culicidae) in the United Kingdom. J Vector Ecol. 2006;31(2):292-304

91. Bayoh MN, Lindsay SW. Effect of temperature on the development of the aquatic stages of Anopheles gambiae sensu stricto (Diptera: Culicidae). Bull Entomol Res. 2007;93(5):375-81.

92. Jeffree $E$, Jeffree $C$. Temperature and the biogeographical distributions of species. Funct Ecol. 1994:8(5):640-50.

93. Paz S, Semenza J. Environmental drivers of West Nile fever epidemiology in Europe and Western Asia - A review. Int J Environ Res Public Health. 2013; 10(8):3543.

94. Evans MV, Dallas TA, Han BA, Murdock CC, Drake JM. Data-driven identification of potential Zika virus vectors. elife. 2017;6:e22053.

95. Beier JC, Zimmerman JH, Kenawy MA, Said SE, Abbassy MM. Host-feeding patterns of the mosquito community (Diptera: Culicidae) in two Faiyum Governorate villages, Egypt. J Med Entomol. 1987;24(1):28-34.

96. Kenawy MA, Beier JC, Zimmerman JH, Said SE, Abbassy MM. Host-feeding patterns of the mosquito community (Diptera: Culicidae) in Aswan Governorate, Egypt. J Med Entomol. 1987;24(1):35-9.

97. Fyodorova MV, Savage HM, Lopatina JV, Bulgakova TA, Ivanitsky AV, Platonova OV, Platonov AE. Evaluation of potential West Nile virus vectors in Volgograd region, Russia, 2003 (Diptera: Culicidae): species composition, bloodmeal host utilization, and virus infection rates of mosquitoes. J Med Entomol. 2006:43(3):552-63.
98. Bagirov G, Gadzhibekova E, Alirzaev G. [The attack activity of Uranotaenia unguiculata Edwards, 1913 mosquitoes on man.] Med Parazitol Parazit Bol. 1994;3:39-40. (In Russian).

99. Tóth S. Mosquito Fauna of Hungary. Nat Somogy. 2004;6:1-327.

100. Braverman Y, Kitron U, Killick-Kendrick R. Attractiveness of vertebrate hosts to Culex pipiens (Diptera: Culicidae) and other mosquitoes in Israel. J Med Entomol. 1991;28(1):133-8.

101. Șuleșco T, von Thien H, Toderaș L, Toderaș I, Lühken R, Tannich E. Circulation of Dirofilaria repens and Dirofilaria immitis in Moldova. Parasit Vectors. 2016;9(1):627.

\section{Submit your next manuscript to BioMed Central and we will help you at every step:}

- We accept pre-submission inquiries

- Our selector tool helps you to find the most relevant journal

- We provide round the clock customer support

- Convenient online submission

- Thorough peer review

- Inclusion in PubMed and all major indexing services

- Maximum visibility for your research

Submit your manuscript at www.biomedcentral.com/submit
) Biomed Central 